\title{
Productivity and Qualitative Characteristics of Varieties of Beets
}

\author{
Pablo W. R. Coutinho ${ }^{1}$, Márcia M. Echer ${ }^{1}$, Paulo S. R. Oliveira ${ }^{1}$, Graciela M. Dalastra ${ }^{1}$, Danielle A. Cadorin ${ }^{1}$ \\ \& Jaqueline Vanelli ${ }^{1}$ \\ ${ }^{1}$ Department of Plant Production, State University of the West of Paraná, Marechal Cândido Rondon, Brazil \\ Correspondence: Pablo W. R. Coutinho, Department of Plant Production, State University of the West of Paraná, \\ Rua Pernambuco, 1599, Marechal Cândido Rondon, Brazil. Tel: 55-91-98862-1784. E-mail: \\ pablowenderson@hotmail.com
}

\author{
Received: March 14, $2018 \quad$ Accepted: Arpil 16, $2018 \quad$ Online Published: May 15, 2018 \\ doi:10.5539/jas.v10n6p327 URL: https://doi.org/10.5539/jas.v10n6p327
}

\begin{abstract}
The objective of this study was to evaluate the physicochemical characteristics, biometric and productivity of beet cultivars. The experiment was conducted in random blocks with four repetition. The treatments were six beet cultivars: Maravilha, Merlot, Kestrel, Itapuã 202, Chata do Egito and Tall Top Early Wonder. These cultivars were evaluated for plant height, leaf number, diameter and length of root, average mass of root and fresh weight of shoot, the root shape index, productivity, the soluble solids, titratable acidity, ratio, $\mathrm{pH}$ and anthocyanin content. The highest average root masses and productivity were observed for the cultivars Maravilha e Tall Top Early Wonder, being similar to Itapuã 202 cultivars and the Boring Egypt. For quality characteristics there was no difference between cultivars for the soluble solids and $\mathrm{pH}$, this was not the same behavior for titratable acidity and ratio. The highest anthocyanin content were observed in cultivars Merlot, Kestrel and Chata do Egito. The cultivars Chata do Egito presented the best productivity and quality characteristics, for the factors and elements of the elapsed year climate.
\end{abstract}

Keywords: Beta vulgaris, physicochemical characteristics, anthocyanin content

\section{Introduction}

The production of vegetables is an agroeconomic activity in which the application of technologies such as the use of fertilizers, fungicides and hybrid cultivars represent the difference between high and low productivity, thus determining the good or poor quality of the product, which ends up being reflected in the income of the producer. Therefore, the introduction of hybrid cultivars that show good adaptation in relation to genotype and environment, resistance to foliar fungal diseases and greater precocity in relation to traditional cultivars, always aiming at the quality and uniformity of the product.

The beet [Beta vulgaris L. var. Crassa (Alef.) J. Helm] is a herbaceous biennial vegetable belonging to the family Quenopodiaceae, where it is classified into three types: olerácea beet, or table beet, sugar beet and forage beet, the table-top beet, due to the growth in consumption in the domestic market, where the largest producers in Brazil are the South and Southeast. However, this vegetable is native to temperate regions of Europe, North Africa and West Asia (Filgueira, 2013). The edible part is its tuberous root, which is globular in shape (Costa, Vasconcelos, Silva, \& Ness, 2008), red to purplish-red in color due to the presence of the betalaine pigments, which are important antioxidants (Araújo Filho, Eidam, Borsato, \& Raupp, 2011).

The beet stands out for being a root rich in nutritional properties, such as sugar, vitamins, potassium, iron, sodium, copper and zinc (Alves, Prado, Gondim, Fonseca, \& Cecílio Filho, 2008; Araújo Filho et al., 2011), as well as presenting medicinal properties, providing protection and prevention against oxidative stress and some cancers (Alves, J. M. David, J. P. David, Bahia, \& Aguiar 2010).

The cultivation of the beet crop is relatively short and the environment exerts a great interference on the quality of its roots, being highly demanding as to the acidity of the soil. The according by Trani, Tivelli, Factor, and Breda Júnior (2013), another factor that may affect the commercial productivity of beet is the incidence of root lesions, which can decrease with correct application of boron, since this micronutrient presents action on root quality.

There are several studies carried out with test of cultivars of vegetables on the most diverse situations presenting diverse performances and indicating a significant interaction between genotype and environment (Bertini, 
Pinheiro, Nóbrega, \& Duarte, 2010; Biesdorf, Silva, Biesdorf, Oliveira, \& Conten, 2015; Couto, Moreira, \& Junior, 2015; A. O. Silva, E. F. F. Silva, Bassoi, \& Klar, 2015a), thus demonstrating that different genetic materials respond differently to environmental factors.

The search for beet cultivars more adapted to the local conditions is of paramount importance, since the majority has North American or European origin, being that in Brazil there are few cultivars used for production. In this sense, the objective of this work was to evaluate the physicalchemical, biometric and productivity characteristics of beet cultivars.

\section{Material and Methods}

The experiment was conducted under field conditions, at the Experimental Station "Antônio Carlos dos Santos

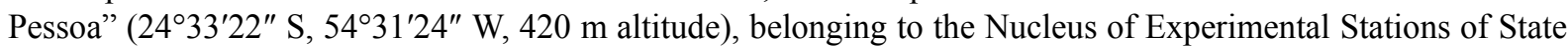
University of the West of Paraná, Campus Marechal Cândido Rondon, PR, during the period of May to September of 2015.

The climate of the region, according to the Köppen classification, is Cfa-subtropical climate, with average temperature in the coldest month below $18{ }^{\circ} \mathrm{C}$ (mesothermic) and average temperature in the hottest month above $22{ }^{\circ} \mathrm{C}$, With hot summers, infrequent frosts and tendency of rain concentration in the summer; however, without definite dry period. The annual precipitation varies from 1,800 to $2,000 \mathrm{~mm}$, with average temperature between 22 and $23{ }^{\circ} \mathrm{C}$ (Caviglione et al., 2000).

For the soil chemical characterization, we collected samples throughout the experimental area, at a depth of 0 to $0.20 \mathrm{~m}$, with pH results $\left(\mathrm{CaCl}_{2}\right)=5.85 ; \mathrm{MO}=24.61 \mathrm{~g} \mathrm{dm}^{-3} ; \mathrm{P}($ Mehlich 1$)=134.20 \mathrm{mg} \mathrm{dm}{ }^{-3} ; \mathrm{K}($ Mehlich 1$)=$ $0.85 \mathrm{cmol}_{\mathrm{c}} \mathrm{dm}^{-3} ; \mathrm{Ca}^{2+}=5.19 \mathrm{cmol}_{\mathrm{c}} \mathrm{dm}^{-3} ; \mathrm{Mg}^{2+}=3.70 \mathrm{cmol}_{\mathrm{c}} \mathrm{dm}^{-3} ; \mathrm{Al}^{3+}=0 \mathrm{cmol}_{\mathrm{c}} \mathrm{dm}^{-3} ; \mathrm{SB}=9.74 \mathrm{cmol}_{\mathrm{c}} \mathrm{dm}^{-3}$; $\mathrm{CTC}=12.59 \mathrm{cmol}_{\mathrm{c}} \mathrm{dm}^{-3} ; \mathrm{H}+\mathrm{Al}=2.55 \mathrm{cmol}_{\mathrm{c}} \mathrm{dm}^{-3}$ and $\mathrm{V}=77.36 \%$. The soil of the experimental area is eutroferric Red Latosol, clay texture.

The experimental design was a randomized complete block design, with four replications. The treatments consisted of the beet cultivars Maravilha, Merlot, Kestrel, Chata do Egito, Tall Top Early Wonder and Itapuã 202. The latter, the only one of national origin.

The experimental units consisted of $1.44 \mathrm{~m}^{2}$ portions, totaling 24 experimental units, comprising plots formed by 44 plants distributed in beds of four rows, spacing $0.30 \mathrm{~m}$ between rows and $0.10 \mathrm{~m}$ between plants, being selected to evaluate the two central lines of the plot, eliminating the extremities.

All cultivars were characterized according to Tivelli et al. (2011), presenting the shape of the globular root, coloring from deep red to dark purple, and foliage height between 40 and $55 \mathrm{~cm}$.

Seedlings were produced in 200-expanded cell polystyrene trays containing commercial vegetable substrate, with the composition based on pine bark, peat, charcoal and vermiculite. These were kept in a greenhouse until transplant period to the field, which occurred when they had 5 to 6 definitive leaves ( 28 days after sowing for both cultures). Irrigation occurred according to the need, with irrigators.

The fertilization of planting and cover were carried out following the recommendations by Trani et al. (2013) and $40 \mathrm{~kg} \mathrm{ha}^{-1}$ of N, $80 \mathrm{~kg} \mathrm{ha}^{-1}$ of $\mathrm{P}_{2} \mathrm{O}_{5}, 30 \mathrm{~kg} \mathrm{ha}^{-1}$ of $\mathrm{K}_{2} \mathrm{O}$ and $1 \mathrm{~kg} \mathrm{ha}^{-1}$ of B were applied to the plantation and $120 \mathrm{~kg} \mathrm{ha}^{-1}$ of N, plus $60 \mathrm{~kg} \mathrm{ha}^{-1}$ of $\mathrm{K}_{2} \mathrm{O}$, using as nitrogen, phosphorus, potassium and boron sources, urea, triple superphosphate, potassium chloride and boric acid, respectively.

Irrigation was carried out by spraying and, in order to mitigate the impact of water with the soil and the emergence of weeds, Tifton straw was used as mulch on the beds. Manual weed control was performed and there were no phytosanitary problems.

An evaluation was performed 79 days after the transplant, being: plant height (from the soil level to the highest leaf end), number of leaves, fresh weight of the air part, root diameter and length, index of root format (diameter of the root/length of the root), mean mass and commercial root productivity (determined from the fresh mass of the total roots of ten central plants, free of cracks, bifurcations, nematodes, secondary roots and mechanical damages).

Physicochemical characteristics of the beet were evaluated according to the soluble solids content (SS), titratable acidity (TA), ratio (SS/TA) and hydrogenionic potential $(\mathrm{pH})$. Direct method determined soluble solids by using a WYA digital refractometer, model 2WA-J, with results expressed as ${ }^{\circ}$ Brix. Titratable acidity was determined by

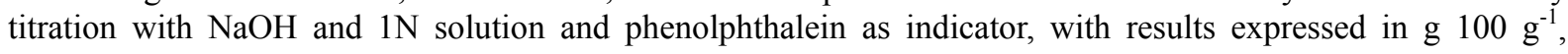
equivalent to citric acid (IAL, 2008). 
The determination of anthocyanin was performed according to the method described by Francis (1982), with some adjustments, from $1 \mathrm{mg}$ of sample added $20 \mathrm{~mL}$ of Tris-HCl buffered acetone. The samples were homogenized and rested in beakers wrapped with aluminum foil, remaining at refrigerated temperature. After this step, the samples were centrifuged for 5 minutes in $2000 \mathrm{rpm}$. The supernatant was removed with a pipette and the absorbance reading was carried out in spectrophotometer at $537 \mathrm{~nm}$ for anthocyanins. The results were

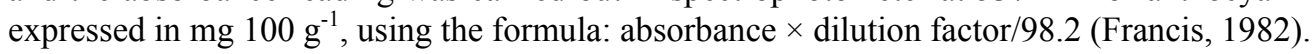

The data were submitted to the normality and homogeneity tests, to the analysis of variance and to the averages compared by the Tukey test $(\mathrm{p} \leq 0.05)$, using the statistical program SISVAR 5.3 (Ferreira, 2011).

\section{Results and Discussion}

The temperature during the work was pleasant, around $20{ }^{\circ} \mathrm{C}$ (Figure 1), thus contributing to the better development of aerial part and internal color of the root. High temperatures reduce the concentration of in pigments, besides contributing to the formation of rings of light coloring. The association of high temperatures and relative humidity favors the occurrence of Cercospora beticola, causing the reduction of the leaf area and thus reducing the production of photoassimilates that could increase its productive potential (Tullio, Otto, Boer, $\&$ Ohse, 2013), being that in this work the cultivars used showed good tolerance to disease.

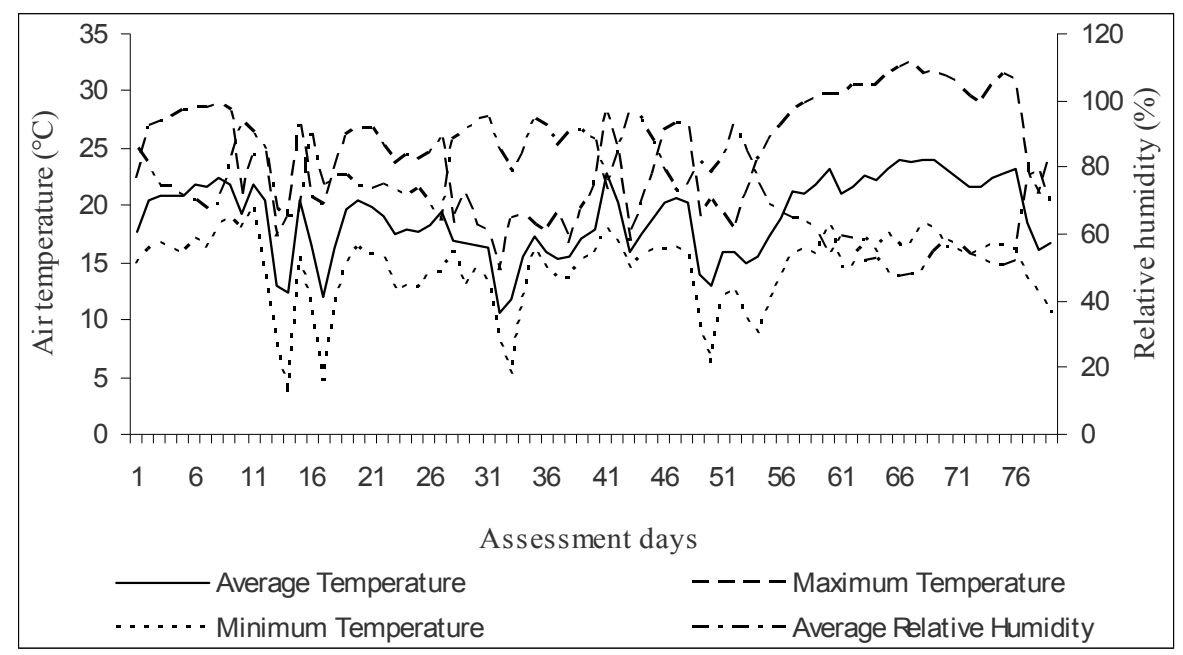

Figure 1. Mean, minimum and maximum values of air temperature and mean relative air humidity per day, during the cycle of beet cultivars, in Marechal Cândido Rondon/PR-2015

The cultivars presented differences in plant height and number of leaves. The diameter, length and root index format did not differ between the cultivars (Table 1).

The Maravilha exceeded Kestrel in plant height, which is a genetic trait which to grow quite reach $55 \mathrm{~cm}$ in height and foliage to grow Kestrel $50 \mathrm{~cm}$ (Tivelli et al., 2011). The cultivar Tall Top Early Wonder showed superior heights observed by Zárate et al. (2008), who observed heights of $23.16 \mathrm{~cm}$. On the other hand, Gondim, Correia, Alves, Prado, and Cecílio Filho (2011) corroborates this work, since they obtained heights of $49.5 \mathrm{~cm}$ in a hydroponic system for the same cultivar. 
Table 1. Plant height (PH), number of leaves (NL), root diameter and length (RD and RL), root shape index (RSI) for beet cultivars, in Marechal Cândido Rondon/PR-2015

\begin{tabular}{llllll}
\hline Cultivars & PH $(\mathrm{cm})$ & NL & RD $(\mathrm{mm})$ & RL $(\mathrm{mm})$ & RSI \\
\hline Maravilha & $54.25 \mathrm{a}$ & $10.31 \mathrm{bc}$ & 74.30 & 71.63 & 1.06 \\
Merlot & $42.60 \mathrm{ab}$ & $12.25 \mathrm{ab}$ & 66.54 & 60.28 & 1.12 \\
Kestrel & $40.41 \mathrm{~b}$ & $13.21 \mathrm{a}$ & 67.82 & 61.37 & 1.13 \\
Itapuã 202 & $46.99 \mathrm{ab}$ & $9.89 \mathrm{c}$ & 75.94 & 67.12 & 1.15 \\
Chata do Egito & $52.40 \mathrm{ab}$ & $10.70 \mathrm{bc}$ & 72.18 & 67.25 & 1.09 \\
Tall Top Early Wonder & $49.25 \mathrm{ab}$ & $13.51 \mathrm{a}$ & 79.31 & 67.72 & 1.19 \\
CVs (\%) & 11.08 & 8.54 & 8.00 & 8.80 & 11.09 \\
\hline
\end{tabular}

Note. Averages followed by the same lowercase letter in the columns did not differ statistically from each other, Tukey test of in 1 a $5 \%$ probability.

To cultivate Itapuã was observed heights near those found by A. O. Silva, E. F. F. E. Silva, and Klar (2015b), worked with the management of Fertigation and levels of salinization of the soil, when the management of fertirrigation was controlled.

The highest number of leaves was observed in the cultivars Merlot, Kestrel and Tall Top Early Wonder (Table 1). These results demonstrate that there are genetic differences between cultivars, with this increased number of leaves on plants with lower heights can result in a self shadowing on cultivating Kestrel, showing a reduction in vegetative development and consequently productivity (Tullio et al., 2013).

Beet cultivars showed diameters and lengths in the same range as the standardized companies for marketing. This indicates that the cultivars adapted to the growing conditions. Smaller diameter $(64.1 \mathrm{~mm})$ and root length $(52.1 \mathrm{~mm})$ results were observed by Zárate et al. (2008), who worked with the Tall Top Early Wonder cultivate in the number of rows and spacing, when using the same spacing between plants of this work. On the other hand, Gondim et al. (2011) obtained diameters similar to those recorded in this study $(76.7 \mathrm{~mm})$. For your time, Silva et al. (2015a) found superior results to root diameter and length of the cultivate Itapuã, seen that worked with the management of salinity soil Fertigation and what justifies these larger root parameters.

For the root index index, the cultivars did not show any difference between them. Since there is no information for this variable in the literature for beet, however, the supplier firms seeds inform the format of the cultivars with this information, we can say that the roots had a globular shape (Tivelli et al., 2011) because the difference between the diameter and length is small, which is consistent with the information provided by companies.

The average mass of the root, productivity and fresh mass of the air part shoot were different between cultivars (Table 2), showing that there is influence of genetic factor in relation to the growth and development of plant varieties, for this year it was carried out the work.

The smallest fresh pasta from the shoot was observed in the cultivars Merlot and Kestrel (Table 2), resulting in a lower accumulation of photoassimilates, thus reducing the productive potential of the vegetable. According to Tullio et al. (2013), the smallest accumulation of photoassimilates can be both limiting the production of vegetative plant structures, such as formation of roots.

The highest root mean mass and yield were observed in the Maravilha and Tall Top Early Wonder cultivars, which differed from the Melot and Kestrel cultivars, for the factors and elements of the elapsed year climate. Zárate et al. (2010), worked with and without soil cover with poultry litter and piles with cultivate Tall Top Early Wonder and had lower results this work in the average root mass and productivity.

The results of Gondim et al. (2011), corroborated with this work in for average mass of root of Tall Top Early Wonder. However, in the study of Grisa, Toledo, Oliveira, Holz, and Marine (2007), greater mass of roots in the same cultivate. 
Table 2. Root mean mass (RM), root productivity (PROD) and fresh weight of the air part (FW) for beet cultivars, in Marechal Cândido Rondon/PR-2015

\begin{tabular}{llll}
\hline Cultivars & RM $(\mathrm{g})$ & PROD $\left(\mathrm{t} \mathrm{ha}^{-1}\right)$ & FW $(\mathrm{g})$ \\
\hline Maravilha & $198.51 \mathrm{a}$ & $99.26 \mathrm{a}$ & $181.98 \mathrm{ab}$ \\
Merlot & $133.87 \mathrm{~b}$ & $66.94 \mathrm{~b}$ & $97.85 \mathrm{c}$ \\
Kestrel & $137.29 \mathrm{~b}$ & $68.64 \mathrm{~b}$ & $93.19 \mathrm{c}$ \\
Itapuã 202 & $172.39 \mathrm{ab}$ & $86.20 \mathrm{ab}$ & $170.17 \mathrm{~b}$ \\
Chata do Egito & $162.37 \mathrm{ab}$ & $81.19 \mathrm{ab}$ & $167.85 \mathrm{~b}$ \\
Tall Top Early Wonder & $211.07 \mathrm{a}$ & $105.53 \mathrm{a}$ & $212.12 \mathrm{a}$ \\
CVs (\%) & 14.49 & 14.49 & 10.03 \\
\hline
\end{tabular}

Note. Averages followed by the same lowercase letter in the columns did not differ statistically from each other, Tukey test of in 1 a $5 \%$ probability.

The productivity of the beet cultivars in this research is above the national average, which, according to Sediyama, Santos, Vidigal, and Salgado (2011), ranges from 20 to $35 \mathrm{t} \mathrm{ha}^{-1}$. Results of productivity lower than this work were observed in the cultivate Tall Top Early Wonder by Tullio et al. (2013), of $15.1 \mathrm{t} \mathrm{ha}^{-1}$, and by Oliveira, Puiatti, Bhering, Cecon, and Silva (2012) of $42.13 \mathrm{t} \mathrm{ha}^{-1}$.

For the characteristics of quality of root, noted difference between the cultivars to titratable acidity, ratio and anthocyanins. Only soluble solids and $\mathrm{pH}$ did not differ among cultivars (Table 3). Although there is no quality difference, a quality of the root and an inherent characteristic of each cultivate, and can promote the reduction of quality when some cultural treatments are not carried out, because the soil type, soil and climatic conditions, even the lack of nutrients as boron, potassium and nitrogen may result in undesirable quality characteristics such as root shape and taste. Thus, the qualitative and quantitative potential of the crop depends on the genotype and environment interaction, and is thus crucial for the success of the cultivate in a given environment (Freire, Oliveira, Carilho, Oliveira, \& Freitas, 2009).

Table 3. Soluble solids (SS), titratable acidity (TA), ratio (SS/AT), pH and anthocyanin content in beet cultivars, in Marechal Cândido Rondon/PR-2015

\begin{tabular}{llllll}
\hline Cultivars & SS $\left({ }^{\circ}\right.$ Brix $)$ & TA $(\%$ citric acid $)$ & Ratio & $\mathrm{pH}$ & Anthocyanin $\left(\mathrm{mg}^{\left.100 \mathrm{~g}^{-1}\right)}\right.$ \\
\hline Maravilha & 7.80 & $0.14 \mathrm{a}$ & $57.75 \mathrm{~b}$ & 6.27 & $39.63 \mathrm{bc}$ \\
Merlot & 9.01 & $0.14 \mathrm{a}$ & $68.11 \mathrm{~b}$ & 6.21 & $53.00 \mathrm{a}$ \\
Kestrel & 9.05 & $0.12 \mathrm{ab}$ & $80.48 \mathrm{ab}$ & 6.30 & $46.74 \mathrm{ab}$ \\
Itapuã 202 & 8.30 & $0.14 \mathrm{a}$ & $62.15 \mathrm{~b}$ & 6.14 & $19.86 \mathrm{~d}$ \\
Chata do Egito & 8.46 & $0.08 \mathrm{~b}$ & $107.48 \mathrm{a}$ & 6.24 & $38.16 \mathrm{bc}$ \\
Tall Top Early Wonder & 8.11 & $0.11 \mathrm{ab}$ & $76.92 \mathrm{ab}$ & 6.24 & $31.33 \mathrm{c}$ \\
CVs (\%) & 6.17 & 19.37 & 18.52 & 1.09 & 11.96 \\
\hline
\end{tabular}

Note. Averages followed by the same lowercase letter in the columns did not differ statistically from each other, Tukey test of in 1 a $5 \%$ probability.

The soluble solids provides good estimate of the sugar content in plant tissue. Aquino et al. (2006), observed a variation in solids content as a function of nitrogen doses in beets, which presented a range between $8.5^{\circ}$ Brix and $10.4^{\circ}$ Brix.

The cultivate Chata do Egito presented the lowest titratable acidity, not differing from Kestrel and Tall Top Early Wonder. Ramos, Vieites, Daiuto, Furlaneto, and Mendonça (2016) verified superior results compared to the cultivars studied in this work, registering a titratable acidity in cultivating Borus of $1.72 \mathrm{~g}$ citric acid. In this way, it is possible to affirm that this variable presents genetic characteristics inherent to each cultivate.

The ratio values were different for each cultivate studied, with Chata do Egito showing the highest ratio, not differing from Kestrel and Tall Top Early Wonder. This variable represents the relationship between soluble solids and titratable acidity, thus, the balance between sugars and organic acids present in vegetables.

In some vegetables the relation that provides the best balance has already been determined. In the case of beet Ramos et al. (2016), obtained a ratio of 95.9 in the cultivate Borus, demonstrating in this way that each cultivate 
presents a ratio. This characteristic is represented by the balance between sugars and organic acids, being related to the taste.

The minimum $\mathrm{pH}$ variations showed that there was no difference between the cultivars tested, being in the range of 6.21 and 6.30. Inferior results (5.87) were observed by Ramos et al. (2016). Both also observed little variation in the $\mathrm{pH}$, since it is characteristic edependent of the culture environment.

The anthocyanin content can be presented as a criterion of choice of cultivate, as well as productivity, because of the benefits to health, because this pigment has recognized antioxidade activity (Strack, Vogt, \& Schliemann, 2003). The Merlot cultivate presented the highest concentration of anthocyanins ( $53.00 \mathrm{mg}$ in $100 \mathrm{~g}$ of sample), but not differing from the cultivate Kestrel (46.74 $\mathrm{mg}$ in $100 \mathrm{~g}$ of sample). Anthocyanins are responsible for the coloration of the root, ranging from intense red to dark purple, being an inherent characteristic of each cultivate.

The Merlot cultivars and Kestrel presented the smallest average mass of root and productivity, for the factors and elements of the elapsed year climate. On the other hand, the Itapuã 202 presented the lowest anthocyanin content, demonstrating that the cultivars showed a diversified behavior in the productive and qualitative characteristics in this culture environment.

\section{Conclusion}

The studied performance of the cultivars presented vegetative, productive and physicochemical aspects differentiated for the edaphoclimatic conditions of the West of Paraná, for the factors and elements of the elapsed year climate. The cultivars Chata do Egito presented the best qualitative and quantitative characteristics when compared to the others studied.

\section{References}

Alves, A. U., Prado, R. M., Gondim, A. R. O., Fonseca, I. M., \& Cecílio Filho, A. B. (2008). Desenvolvimento e estado nutricional de beterraba em função da omissão de nutrientes. Horticultura Brasileira, 26(2), 292-295. https://doi.org/10.1590/S0102-05362008000200033

Alves, C. Q., David, J. M., David, J. P., Bahia, M. V., \& Aguiar, R. M. (2010). Métodos para determinação de atividade antioxidante in vitro em substratos orgânicos. Química Nova, 33(10), 2202-2210. https://doi.org/ 10.1590/S0100-40422010001000033

Aquino, L. A., Puiatti, M., Pereira, P. R. G., Pereira, F. H. F., Ladeira, I. R., \& Castro, M. R. S. (2006). Produtividade, qualidade e estado nutricional da beterraba de mesa em função de doses de nitrogênio. Horticultura Brasileira, 24(2), 199-203. https://doi.org/10.1590/S0102-05362006000200015

Araújo Filho, D. G., Eidam, T., Borsato, A. V., \& Raupp, D. S. (2011). Processamento de produto farináceo a partir de beterrabas submetidas à secagem estacionária. Acta Scientiarum Agronomy, 33(2), $207-214$. https://doi.org/10.4025/actasciagron.v33i2.4885

Bertini, C. H. C. M., Pinheiro, E. A. R., Nóbrega, G. N., \& Duarte, J. M. L. (2010). Desempenho agronômico e divergência genética de genótipos de coentro. Revista Ciência Agronômica, 41(3), 409-416. https://doi.org/ 10.1590/S1806-66902010000300013

Biesdorf, E. M., Silva, J. S., Biesdorf, E. M., Oliveira, O. J., \& Conten, M. V. D. (2015). Desempenho agronômico de cultivares de alho vernalizado e não vernalizado na região Sudeste de Mato Grosso. Revista de Agricultura Neotropical, 2(3), 44-48.

Caviglione, J. H., Kiihl, L. R. B., Caramori, P., \& Oliveira, D. (2000). Cartas climáticas do Paraná (V. 1.0). Londrina: Instituto Agronômico do Paraná.

Costa, R. N. T., Vasconcelos, J. P., Silva, L. A., \& Ness, R. L. L. (2008). Interferência do excesso de água no solo e componentes de produção em beterraba. Horticultura Brasileira, 26(1), 74-77. https://doi.org/10.1590/ S0102-05362008000100014

Couto, A. L., Moreira, D. A., \& Junior, P. V. A. (2015). Produção de mudas de cultivares de alface utilizando duas espumas fenólicas em Altamira, Pará. Revista Verde, 10(1), 201-207. https://doi.org/10.18378/rvads. v10i1.3072

Ferreira, D. F. (2011). Sisvar: A computer statistical analysis system. Ciência e Agrotecnologia, 35(6), 1039-1042. https://doi.org/10.1590/S1413-70542011000600001

Filgueira, F. A. R. (2013). Novo manual de olericultura: Agrotecnologia moderna na produção e comercialização de hortaliças (3th ed.). Viçosa, MG: UFV. 
Francis, F. J. (1982). Analysis of anthocyanins. In P. Markakis (Ed.), Anthocyanins as food colors (1st ed.). New York: Academic Press. https://doi.org/10.1016/B978-0-12-472550-8.50011-1

Freire, A. G., Oliveira, F. A., Carilho, M. J. S. O., Oliveira, M. K. T., \& Freitas, D. C. (2009). Qualidade de cultivares de alface produzida em condições salinas. Revista Caatinga, 22(4), 81-88.

Gondim, A. R. O., Correia, M. A. R., Alves, A. U., Prado, R. M., \& Cecílio Filho, A. B. (2011). Crescimento e marcha de acúmulo de nutrientes em plantas de beterraba cultivadas em sistema hidropônico. Bioscience Journal, 27(4), 526-535.

Grisa, S., Toledo, M. V., Oliveira, L. C., Holz, L., \& Marine, D. (2007). Análise quantitativa de plantas de beterraba tratadas com preparados homeopáticos de staphysagria. Revista Brasileira de Agroecologia, 2(2), 1046-1049.

IAL (Instituto Adolfo Lutz). (2008). Normas Analíticas do Instituto Adolfo Lutz. Métodos físico-químicos para análises de alimentos (4th ed.). São Paulo: IAL.

Oliveira, N. L. C., Puiatti, M., Bhering, A. S., Cecon, P. R., \& Silva, G. C. C. (2012). Uso de urina de vaca no cultivo da beterraba de mesa. Revista Brasileira de Agropecuária Sustentável, 2(2), 7-13. https://doi.org/ 10.21206/rbas.v2i2.161

Ramos, J. A., Vieites, R. L., Daiuto, E. R., Furlaneto, K. A., \& Mendonça, V. Z. (2016). Modificação da composição físico química de beterrabas submetidas a diferentes tipos de cortes e métodos de cocção. Revista Energia na Agricultura, 31(1), 97-101. https://doi.org/10.17224/EnergAgric.2016v31n1p108-120

Sediyama, M. A. N., Santos, M. R., Vidigal, S. M., \& Salgado, L. T. (2011). Produtividade e exportação de nutrientes em beterraba cultivada com cobertura morta e adubação orgânica. Revista Brasileira de Engenharia Agrícola e Ambiental, 15(9), 883-889. https://doi.org/10.1590/S1415-43662011000900002

Silva, A. O., Silva, E. F. F. E., \& Klar, A. E. (2015b). Manejo da fertirrigação e salinidade do solo no crescimento da cultura da beterraba. Revista de Engenharia Agrícola, 35(2), 230-241. https://doi.org/10.1590/ 1809-4430-Eng.Agric.v35n2p230-241/2015

Silva, A. O., Silva, E. F. F., Bassoi, L. H., \& Klar, A. E. (2015a). Desenvolvimento de cultivares de beterraba sob diferentes tensões da água no solo. Horticultura Brasileira, 33(1), 12-18. https://doi.org/10.1590/ S0102-053620150000100003

Strack, D., Vogt, T., \& Schliemann, W. (2003). Recent advances in betalain research. Phytochemistry, 62(3), 247-269. https://doi.org/10.1016/S0031-9422(02)00564-2

Tivelli, S. W., Factor, T. L., Teramoto, J. R. S., Fabri, E. G., Moraes, A. R. A., Trani, P. E., \& May, A. (2011). Beterraba: do plantio à comercialização (1st ed.). Campinas, SP: IAC.

Trani, P. E., Tivelli, S. W., Factor, T. L., \& Breda Júnior, J. M. (2013). Calagem e adubação da beterraba (1st ed.). Campinas, SP: IAC.

Tullio, J. A., Otto, R. F., Boer, A., \& Ohse, S. (2013). Cultivo em ambientes protegido e natural na época de verão. Revista Brasileira de Engenharia Agrícola e Ambiental, 17(10), 1074-1079. https://doi.org/10.1590/ S1415-43662013001000008

Zárate, N. A. H., Sangalli, C. M. S., Vieira, M. C., Graciano, J. D., Munarin, E. E. O., \& Paula, M. F. S. (2010). Cobertura do solo com cama-de-frango, com e sem amontoa, na produção de beterraba. Ciências e Agrotecnologia, 34, 1598-1603. https://doi.org/10.1590/S1413-70542010000700002

Zárate, N. A. H., Vieira, M. C., Rech, J., Graciano, J. D., Gomes, H. E., \& Pontim, B. C. A. (2008). Número de fileiras no canteiro e espaçamento entre plantas na produção e na rentabilidade de beterraba em Dourados, estado do Mato Grosso do Sul. Acta Scientiarum Agronomy, 30(3), 397-401. https://doi.org/10.4025/ actasciagron.v30i3.3550

\section{Copyrights}

Copyright for this article is retained by the author(s), with first publication rights granted to the journal.

This is an open-access article distributed under the terms and conditions of the Creative Commons Attribution license (http://creativecommons.org/licenses/by/4.0/). 